11.Sultangareeva R.A. Semeino-bytovoi obrädovyi fölklor başkirskogo naroda. - Ufa: Gilem, 1998. $234 \mathrm{~s}$.

12.Jünısov A. Fäniden baqiğa deiın. - Almaty: Qainar. 1994. - 117 b.

13.Arğynbaev H. Qazaq otbasy: (qazaq otbasynyñ keşegısl men bügingısl jaiyndă̆y ğylymi zertteu eñbek). - Almaty: Qainar, 1996. - 226 b.

14.Kerım Ş. Qazaq jūmbağy. - Almaty: Arys, 2007.

15.Köpeev M. Aspan, jer jäne adam jaratylysy turaly // Qazaq tarihy. - 1995. - №2. -56-61 b.

16.Qasqabasov S. Janazyq: Är jylğy zertteuler. - Astana: Audarma, 2002. - 548 b.

17.Küieu keltır, qyz üzat, toiyñdy qyl. - Almaty: Sanat, 1994. - 240 b.

18.Tal besıkten jer besıkke deiın (Qazaqtỹ̃ otbasylyq ğüryp jyrlary). Qūrast., alğy sözı men tüsınıkterın jazğan K. Islämjanūly. - Almaty: Ana tıl. 1995. - 272 b.

19. Altynsarin Y. Tañdamaly şyğarmalary. - Almaty: Ğylym, 1994. - 228 b.

МРНТИ 17.07.29

https://doi.org/10.51889/2020-2.1728-7804.75

\author{
Zholmakhanova A. ${ }^{l}$ \\ ${ }^{l}$ Korkyt Ata Kyzylorda State University, \\ Kyzylorda, Kazakhstan
}

\title{
TURKISH PERIOD IN LITERATURE OF KAZAKH DIASPORA
}

Abstract

Until Kazakhstan gained independence, Soviet ideology did not provide an opportunity to study the socio-economic, political and spiritual life of Kazakh people who are living abroad. Moreover, such scientific directions as diasporology, emigrantology did not receive proper development.

The article "Turkish period in the literature of Kazakh diaspora" is the result of the latest research in Kazakh literary science. This article is about the memories of Kazakh people living in Turkey, their genre, artistic and ideological, style features, nostalgic motives inherent in the memories. The historical and cognitive nature of the memories is also examined.

Later, Kazakh emigrants who were arrested during the Second World War and forced to stay abroad, frigntening of returning to the country because of the policy of the Soviet regime in their relation, joined them. One of them is the famous musician Alim Almat. The mentioned representatives of Kazakh emigrant intelligentsia had the opportunity to develop their work in Turkey.

As a result, historical memories were written and published about H. Oraltay, H. Altai, A.Almat about the life of Kazakh diaspora abroad. The author devotes his research to the study of Turkish period of Kazakh diasporal literature.

Keywords: literature, diaspora, genre, diasporology, novel, emigration, Kazakh diaspora, history, emigrant literature, Kazakh literature

\author{
Жолиаханова $A .{ }^{1}$ \\ ${ }^{1}$ Қорқыыт Ата атындавы Қызылорда мемлекеттік университеті, \\ Қызылорда, Қазақсттан
}

\section{ҚАЗАҚ ДИАСПОРАЛЫК ӘДЕБИЕТІНІН ТУРКИЯ КЕЗЕНІ}

\section{Аң̧датпа}

Қазақстан тәуелсіздік алғанға дейін шет елдердегі қазақтар, олардың әлеуметтік-экономикалық, саяси-рухани өмірі туралы зерттеуге кеңестік идеология мүмкіндік бермеді. Тіптен диаспорология, эмигрантология сияқты ғылым салалары да өз дәрежесінде зерттеу жүргізе алмады. Тәуелсіздіктен кейін ғана қазақ ғалымдары шет елдердегі қазақтардың өмірі туралы зерттеуге мүмкіншілік алды. 
«Қазақ диаспоралық әдебиетінің Түркия кезеңі» атты мақала да қазақ әдебиеттану ғылымындағы тың зерттеулердің нәтижесі. Аталған мақалада Түркия қазақтарының естеліктері, оның жанрлық, көркемдік-идеялық, стильдік ерекшеліктері, естеліктердегі «сағыныш сарыны» туралы сөз болады. Естеліктердің тарихи-танымдық сипаты зерделенеді.

Кейінірек олардың қатарын Екінші дүниежүзілік соғыста тұтқынға түсіп, еліне қайтуға Кеңес саясатынан қорқып шетелдерде қалуға мәжбүр болған қазақ эмигранттары толықтырды. Солардың бірі белгілі музыкант - Әлім Алмат болатын. Аталған қазақ эмигрант-зиялылары Түркия мемлекетінде өз шығармашылықтарын дамытты. Соның нәтижесінде Х.Оралтайдың, Х.Алтайдың, Ә.Алматтың шетелдердегі қазақ диаспорасының өмірі туралы тарихи естеліктері жазылып, жарыққа шықты.

Автор өз зерттеуін қазақ диаспоралық әдебиетінің Түркия кезеңіне арнай отырып, осы кезең өкілдерінің шығармашылықтарын зерделейді.

Түйін сөздер: әдебиет, диаспора, жанр, диаспорология, роман, эмиграция, қазақ диаспорасы, тарих, эмигранттық әдебиет

\author{
Жолмаханова A. ${ }^{l}$ \\ ${ }^{1}$ Кызылординский государственный университет имени Коркыт Ата, \\ Кызылорда, Казахстан
}

\title{
ТУРЕЦКИЙ ПЕРИОД В ЛИТЕРАТУРЕ КАЗАХСКОЙ ДИАСПОРЫ
}

\section{Аннотаичя}

До обретения Казахстаном независимости советская идеология не предоставляла возможности для изучения социально-экономической, политико-духовной жизни казахов, проживающих за рубежом. Более того, не получили должного развития и такие научные направления, как диаспорология, эмигрантология.

Статья «Турецкий период в литературе казахской диаспоры» является результатом новейших исследований в казахской литературоведческой науке. В данной статье речь идет о воспоминаниях казахов, проживающих в Турции, их жанровых, художественно-идейных, стилевых особенностях, о ностальгических мотивах, присущих воспоминаниям. Также исследуется историко-познавательный характер воспоминаний.

Позднее их ряды пополнили казахские эмигранты, которые были арестованы в ходе Второй мировой войны и вынуждены остаться за рубежом, опасаясь вернуться в страну из-за политики Советской власти в их отношении. Один из них - известный музыкант Алим Алмат. Упомянутые представители казахской эмигрантской интеллигенции имели возможность развивать свое творчество в Турции.

В результате были написаны и изданы исторические воспоминания Х. Оралтая, Х. Алтая, А. Алмата о жизни казахской диаспоры за рубежом.

Автор посвящает свое исследование изучению Турецкого периода казахской диаспоральной литературы.

Ключевые слова: литература, диаспора, жанр, диаспорология, роман, эмиграция, казахская диаспора, история, эмигрантская литература

1. Introduction. According to the researchers, Kazakh people began to settle in Turkey about 70 years ago. The ancestors of today's Kazakh people of Turkey moved here in the second half of the 1930s from the Altai, Barkul, Sauan, Gaskol regions of East Turkestan. First they crossed through Hansa, Shynkai, crossed the deserts of the Himalayas and Taklamakan, and through India and Pakistan reached Turkey. Many of our compatriots died during the period of resettlement. About two thousand survived Kazakh people settled in Turkey.

The Turkish government favored Kazakh immigrants. They were assisted so that they could live with dignity on the land of fraternal Turkey.

Therefore, Turkish Kazakh people annually visit Menderes Mausoleum in Istanbul district of Topkapi, where they read Koran to express their gratitude to Turkish people. Menderes was one of those who sheltered the first Kazakh immigrants. 
In 1991, when Kazakhstan declared its independence, fraternal Turkey was the first to recognize our young state among other countries of the world.

The fact that science is closely connected with the development of society and must meet its new needs is quite natural. Indeed, scientific novelty is the result of relevance, necessity. This applies not only to the technical, technological sphere, but also to the political, social, humanitarian sphere of science.

After Kazakhstan gained independence, new tasks were set before the country's science. One of them is conducting research on the life and life of Kazakh people living abroad, on their traditions, literature and culture, ethnography, the reasons for the resettlement and its stages [1].

Currently, over 5 million Kazakh people live outside of Kazakhstan in 25 countries of the world. This is about third of the whole Kazakh people on the earth.

In different countries of the world, Kazakh people have different political, economic, cultural and social status.

Kazakh people as permanent population (residents) live in Russia, Turkey, China, Mongolia, Uzbekistan, Western Europe and some US states.

2. Methodology. To the present day, we have not had the opportunity to explore the lives of our compatriots abroad. "After all, until independence, the culture of foreign Kazakh people was not studied, moreover, in the system of social sciences there was no diasporology that would deal with the problems of our compatriots living far from the homeland" [2].

There are several reasons for this. The most important of them - during the period of the Soviet Union of the republics, which were included in its composition did not have the opportunity to independently defend their interests, to form their own ideology. In this regard, research work was subordinated to the "center". Such "chauvinistic" principles in relation to national science also influenced to the development of Kazakh science.

After Kazakhstan gained independence, new horizons and new opportunities were opened for domestic science. The "white spots" in national history were rethought, explored again, which allowed fresh look at many events of the past. In the system of social sciences, research has begun new direction - problems of Kazakh people abroad.

In literature science, the latest topics, such as Kazakh foreign literature, Kazakh foreign folklore, diasporal literature, emigrant literature, have also become the object of research.

We learned about the history, formation and development of Kazakh foreign literature, about its representatives, got acquainted with their work. At the same time, Kazakh literature of Turkey occupies special place, where about 30 thousand Kazakh people live.

3. Result. The writer Khalifa Altai, known for his civic identity among the Turkish people, was born in 1917 in Altai Territory of East Turkestan. His parents were quite authoritative, intelligent people at home. Together with Kazakh people, who opposed the pressure of the Chinese authorities in the 1930s, in 1941 he moved through Tibet to India. For more than ten years, Khalifa Altai lived in India and Pakistan, where he received his education. In 1951, in Pakistan, he created society of Kazakh immigrants under the name Sharki Turkestan, becoming his secretary.

Having united around the society of Kazakh immigrants created by him, he did much to educate, educate Kazakh people of Pakistan, preserve the national language and religion. In 1953-1954, through this society, he organized the resettlement of Kazakh people of Pakistan to our relative Republic of Turkey.

On arrival in Turkey, Khalifa Altai continued his educational activities and made a great contribution to the preservation and development of national history, literature and culture, native language among Kazakh people of Turkey.

As the result of such activities, positive attitude towards the Kazakh people who were engaged in trade was formed in Turkey, which contributed to improving their living conditions and getting an education. In 1977, his first book, "Family tree of Kazakh Turks" in Turkish, was published in Istanbul.

Khalifa Altai is a specialist theologian who had deeply mastered the history and theory of Islam, polyglot who spoke several Eastern languages.

Among his works, the work "The Way of the Quran and the Requirements of Faith", which was published in Kazakh in 1980, is of the particular important works. He is also one of the first translator of the Quran Karim.

In 1988, together with Dalelhan Zhanaltai in Istanbul, he published "Interpretation of the Quran of Karim in the Kazakh language." He also translated books into the Kazakh language such as "Biography of the Prophet Muhammad Halaissalam", "Selected Hadith", "A Brief History of Islam". 
We can say the books of Khalifa Altai - :Gibadatul islam", "The alphabet of quran and the conditions of faith", "Sharia", "Imanshart", "Science" and others are the main contribution to Kazakh theology.

The theme of the fate of Altai Kazakh people plays special role in the work of Khalifa Altai. In his memoirs - "My Memoirs", "From Fatherland to Anadola", "People Relocated from Altai" - he tells about the fate of Altai Kazakh since the resettlement of their ancestors, about Kazakh batyrs who showed courage in overcoming the difficulties of resettlement, in fight against enslavement.

«My Memories» were published in 2014. In the Preface to his work, Khalifa Altai noted that, whenever possible, he tried to accurately indicate, along with the dates of events, the names of localities, the names of people [3. 6].

What the author is talking about is one of the requirements for recollections, and at the same time its foundation. Khalifa Altai, who set himself this task, achieved his creative goal. The events, which are narrated in the memoirs, reflect the real picture of the resettlement of Kazakh people who suffered from Chinese repressions.

It is impossible to read pages without excitement about the difficulties who had Kazakh people, who left the land of their ancestors, about the repressions that fell on their lot. Here is how it was said in the book of H.Altai memoirs «People resettled from Altai» "Who knows what fate will curse us for, the local authorities again look at us. If only one would give us helping hand, he suggested what to do. Dungans forcibly take horses from Kazakh people, forced to relocate from their native places. They take by force selected horses and put their stamps. We have lost our swift horses " [4. 27-28].

Khalifa Altai - a writer who knew several Turkish, Oriental languages, deeply studied the history and theory of religion. From his youth he lived in various countries. Despite some remoteness from Kazakh people-speaking environment, he did not use borrowed lexis in the narrative language.

The fact that $\mathrm{H}$. Altai expressed the events that fell to the lot of Kazakh people who migrated from East Turkestan was narrated in the form of memoirs, testified to the author's creative approach to the search for new genres.

4. Discussion. In the book - the narrative "My Memoirs", which is discussed, and in the book of memoirs "The People Moved from Altai", the core event of the description is the same event. Such artistic searches were before in the history of literature.

One of the features of the memoir genre is that the composition, reflecting real life, at the same time tells about our national history. These qualities of memories make them especially valuable for literary science. In this regard, it is necessary to note the historical significance of the memoirs of H. Altai [5].

This work can be regarded as an invaluable work in which the author without any embellishment tells about the difficulties of that time, about what he saw, about the nostalgia of our compatriots on the land of their fathers. And at the same time, it paints vivid pictures of the multi-layered history of our people.

Speaking about Kazakh literature in Turkey, we should pay more attention to the work of Hassan Oraltai. He is the author of several journalistic, historical, research works written in Turkish, Kazakh, English, German and other languages. It can be said that his research work and journalistic work are "Kazakh Turkish of East Turkestan on the Way to Freedom" (Izmir, 1961), "The Great Turkologist Magzhan Zhumabayuly" (Izmir, 1965), "Main Problems in the History of East Turkestan" (Istanbul, 1975), "The Fight against Communism" (Izmir, 1965) indicate the existence of Kazakh diasporal literature and science.

Despite the fact that Kazakh science and history did not conduct research on Alash intelligentsia, he published research papers about "Alash movement", "Alash Orda" party, and Alash.

Hassan Oraltay studied the activities of representatives of Alash movement on the way of national liberation - A. Bokeikhanov, A. Baitursynov, M. Tynyshbaev, M. Dulatov, Zh. Dosmukhamedov, H. Dosmukhamedov, M. Shokai, M. Zhumabaev, R. Marsekov, T. Ryskulov, S. Asfendiyarov, N. Torekulov, O. Zhandosov, S. Kozhanov and others.

Beginning from 1967, he worked at "Azattyk" radio station in Munich, put a lot of effort in conveying truths to history, society, and time to Kazakh people around the world. Hassan Oraltai was one of the first to give fair assessment of the December events of 1986.

Hassan Oraltay is the successor of the first Kazakh emigrant Mustafa Shokai. He was the son of Kalibek Hakim, who during the national revolution in Xinjiang mobilized Kazakh people of East Turkestan to the national liberation struggle. The name of his father is on the same row with the name of Ospan Batyr, one of the leaders of the national liberation movement of Turkish people in Xinjiang.

In his book of memoirs, "Elim-ailap otken omir (my motherland - passed life)", Hassan Oraltay writes about the life of foreign Kazakh people, taking as the basis of the narrative the events that he himself 
witnessed. In the selection of melodies and motifs "Elim-ai", known since the time of "Aktaban shybyryndy alkakl sulama", there is symbolic subtext. The book tells about the events and historical figures of the period of the 40s of the 20th century and the beginning of the 21st century.

Academician R. Nurgali, analyzing the genre features of the book "Elim-ailap Utken Umir (my motherland - passed life)" noted that this work "of one of the prominent representatives of the foreign Kazakh diaspora, journalist, writer Hassan Oraltay can be called an autobiographical novel" [6].

The volume of the book (50 printed pages), and indeed, the narrative on the coverage of the time period corresponds to the genre of the novel. However, if we analyze the work from the point of view of the requirements for epic works of art (conflict, creation of images, imagination, etc.), then, as the author himself noted, this book belongs to the genre of memories.

Being an experienced journalist, the author conducts his narrative in journalistic style, trying to truthfully and objectively describe the events and images of historical figures.

The author in the Preface to the book of memoirs noted: "Despite to the various obstacles, the book " Elim-ailap onken omir (my motherland - passed life)" reached readers of independent Kazakhstan. Eight hundred copies of the first edition are distributed in Kazakhstan. At the same pace, the book reached Mongolia and my native East Turkestan. The desire of some to prevent the distribution of the book in Kazakhstan, on the contrary, had the opposite effect and contributed to the advertising of the book.

In publications in English, Russian and Kazakh, articles were criticized by those who said that "import of book of memoirs of Khasan Oraltai was banned in Kazakhstan." This also contributed to an increase in the number of people wishing to read the book and find out what is forbidden these days the author writes. The editor-in-chief of the weekly Azat newspaper Batyrkhan Darimbet (since 2002), who noticed this, began to publish excerpts from the book." [7. 5].

After Kazakhstan gained independence, relationship was established with Kazakh people abroad. Researchers began to study the socio-economic, cultural and spiritual life of foreign Kazakh diaspora. For the first time in Almaty, meeting (kuryltai) of foreign Kazakh people was held, where our compatriots from several countries of the world were gathered.

Banning of reading Hassan Oraltai works, is related with that time when he worked 40-years as a journalist and editor of Radio Liberty. After all, the problem has been resolved. Hasan Oraltay has been for several times in Kazakhstan and has taken his place among Kazakh intelligentsia.

The memoirs provide numerous information about Kazakh life abroad, about the fate of the people who moved from East Turkestan. The author tells of the difficult days of trials, about difficult fate that fell our compatriots. The reader is especially touched by the nostalgia of immigrants in their native land, in the land of their ancestors, memories of the past, about unforgettable days in their native land.

Many examples can be given related to Kazakh diasporal literature of Turkish period.

For example, in Turkey, there have been published and made available to Kazakh people the world of art, journalistic works such authoritative, eminent personalities like Dalelhan Zhanaltay, Alim Almat and others. Alim Almat, being in prison, couldn't return home and lived in France, Germany. Then settled in Turkey.

5. Conclusion. Foreign Kazakh literature is an integral part of the national art of the word. And we can say that Kazakh diasporal literature of Turkey, the representatives we named above, made a significant contribution to the development of the national art of the word.

\section{References:}

1 Jolmahanova A. B. Literatura kazahskih diaspor: stanovlenie, razvitie i osobenosti // Gazi Türkiat. [Kazakh diasporal literature: formation, development and features // Gazi Türkiyat.] - 2018. - № 22. - s. 215-223.

2 Zarubejnyi kazahski fölklor: monografia [Foreign Kazakh folklore: monograph]/pod red. B. U. Azibaevoi-Almaty: Evo Press, 2014. - 452 s.

3 Altai H. Moi vospominania. Hroniki etoi istorii. [My memories. Chronicles of the story.] - Almaty, 2014. - $152 \mathrm{~s}$.

4 Altai H. Lüdi, pereselennye s Altaia. [People resettled from Altai.]-Almaty: Dauir, 2014. - 271 s.

5 Jolmahanova A. B İstoricheskoe znachenie memuarov Halifa Altaia // Vestnik RK. Seria «Sosiälnye i gumanitarnye nauki". [The historical significance of Khalifa Altai memoirs // Vestnik RK. Series «Social and Human Sciences».] - Almaty, 2016. - №5 (309). - 164-167 s.

6 Nurgali R. 100 kazahskih romanov. [100 Kazakh novels.] - Astana: Foliant, 2004. - 456 s. 
7 Oraltai H. Elim-ailap otken omir (moia rodina - proşedşaia jizn): Trete izdanie: [Elim-ailap otken omir (my motherland - passed life): Third edition] - Almaty: Bilim, 2005. - 664 s.

МРНТИ 17.71.07

https://doi.org/10.51889/2020-2.1728-7804.76

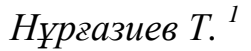 \\ ${ }^{1}$ Ардахан университеті, \\ Ардахан, Түркия
}

\title{
ҚАЗАҚ ЕРТЕГІЛЕРІНДЕГІ МӘДЕНИ-ӘЛЕУМЕТТІК ОРТА
}

Аңдатпа
Ертегілер, бір халықтың ғана емес, адамзат баласының өсу, өркендеу жолын көрсететін тарихи жәдігерлік. Кез келген ертегіде жақсылық пен жамандық, бай мен кедей, туысқандық байланыстар мен отбасын, отанын қорғау сияқты мәселелер сөз етіледі. Сонымен қатар, ертегілер халықтың әлеуметтік өмірін ашық сипаттайтын ерекше қасиетке ие. Бала кезімізден естіп үйреніп қалған бай/кедей, жақсы/жаман, білімді/білімсіз, патша/құл, ақылды/сараңнан басқа ертегілерден баласыздық зары, отағасын күткен ананың уайымы, баланың сана сезімін қалыптастырудың әлеуметтік ерекшелігі, өмір сүрген географиялық орны мен табиғаттың көрінісі, бір сөзбен айтқанда әлеуметтік өмірі көрініс табады. Мақалада осы аталған әлеуметтік ерекшеліктер сараланып, оларға ертегі мәтіндерінен мысалдар келтіріледі. Сонымен қатар мақалада ертегі айтушы/шығарушы және оның өміріндегі әлеуметтік мәселелері ертегіде қалай көрініс тапқандығы туралы айтылады. Мақалада Қазақ әдебиетіндегі Алдар көсе туралы бес ертегі, Алаша Ханның ертегідегі және хикаядағы образының географиялық ерекшелігі, баласы жоқ отбасының “Ер Төстік” ертегісінен көрініс табуы, "Кім күшті" ертегісінің кіріспе бөліміндегі ертегіні айтушының әлеуметтік проблемалары мен бала тәрбиелеудің өзіндік ерекшелігі сөз етіледі.

Түйін сөздер: ертегі, әлеуметтік орта, Ер Төстік, Алдар Көсе, Алаша хан, әлеуметтік код, фольклор

\author{
Nurgaziyev T. ${ }^{1}$ \\ ${ }^{1}$ Ardahan University, \\ Ardahan, Turkey
}

\section{CULTURAL AND SOCIAL ENVIRONMENT OF KAZAKH TALES}

\begin{abstract}
Tales are historical artifacts that show the growth and prosperity of not only one nation, but all of humanity. In any fairy tale there are such questions as good and evil, wealth and poverty, communication with relatives and the protection of the family and homeland. In addition, fairy tales have a special character that clearly describes the social life of people. Rich / poor, good / bad, educated / uneducated, king / slave, smart / mean. In addition, fairy tales reflect such social problems as infertility, mother's anxiety about family and children, social features of the child's consciousness structure, geographical features of social life, in short, a fairy tale reflects the social life of a certain people. The article analyzes social features and provides examples from Kazakh tales. In addition, the article focuses on the storyteller of fairy tales, as he reflects his social problems in the fairy tale. The article examined five tales about Aldar Kos - as a hero-protector of the people i.e. social dreams of the people, geographical features of the image of Alash Khan - urban and nomadic type of khan, the problem of infertility in the fairy tale "Yer Tostik". The narrator's social problems were analyzed based on the tale "Who is Strong".
\end{abstract}

Keywords: fairy tale, social environment, Yer Tostik, Aldar Kose, Alasha Han, social code, folklore 